\title{
PENURUNAN LOGAM BERAT TIMBAL (Pb) PADA LIMBAH CAIR LABORATORIUM KUALITAS LINGKUNGAN UII DENGAN MENGGUNAKAN TUMBUHAN ECENG GONDOK (Eichhornia crassipes)
}

\author{
Eko Siswoyo, Kasam, Dian Widyanti \\ Jurusan Teknik Lingkungan-FTSP, Universitas Islam Indonesia \\ Jl. Kaliurang Km 14,5 Yogyakarta \\ Email : eko_siswoyo@ftsp.uii.ac.id
}

\begin{abstract}
Abstrak
Air limbah laboratorium yang dihasilkan dari kegiatan pengujian dengan menggunakan bahan-bahan kimia merupakan salah satu jenis limbah yang cukup berbahaya karena mengandung beberapa komponen berbahaya. Salah satu komponen tersebut adalah logam berat Timbal (Pb) dengan konsentrasi yang cukup tinggi. Untuk mencegah dampak negatif dari air limbah ini, maka diperlukan suatu upaya pengolahan yang mampu menurunkan kadar dari logam berat tersebut. Pada penelitian ini dipergunakan sistem constructed wetland dengan memanfaatkan tumbuhan air Eceng gondok dan sistem aliran secara batch dan waktu pengamatan selama 12 hari. Reaktor yang dipergunakan terbuat dari kayu yang dilapisi plastik dengan ukuran 1,0 $\times$ 0,5 x 0,5 meter. Variasi air limbah yang dibuat adalah 0\%, $25 \%$, $50 \%$, $75 \%$ dan $100 \%$. Untuk mengetahui peran Eceng gondok, maka dibuat reaktor kontrol yaitu reaktor tanpa tumbuhan air ini. Untuk analisis konsentrasi Pb pada pengujian ini dipergunakan alat Atomic Absorbtion Spectrophotometer (AAS). Dari hasil pengujian diperoleh bahwa efisiensi penurunan tertinggi terjadi pada hari ke-12. Semakin rendah konsentrasi $\mathrm{Pb}$ dalam limbah, maka tingkat penurunan yang terjadi semakin tinggi. Pada konsentrasi limbah $25 \%$ dan $50 \%$ dengan input $0,0318 \mathrm{mg} / \mathrm{l}$ dan $0,0675 \mathrm{mg} / \mathrm{l}$ diperoleh output kurang dari $0,001 \mathrm{mg} / \mathrm{l}$ yang merupakan batas terendah pembacaan AAS yang dipergunakan. Pada konsentrasi air limbah $75 \%$ kemampuan penurunan mencapai $88,86 \%$ sedangkan pada konsentrasi limbah $100 \%$ tingkat penurunan yang terjadi hanya 17,31\%. Peran Eceng gondok terlihat dari adanya perbedaan tingkat penurunan Pb antara reaktor uji dengan reaktor kontrol.
\end{abstract}

Kata Kunci : Air Limbah laboratorium, constructed wetland, eceng gondok, , timbal (Pb)

\begin{abstract}
Laboratory wastewater is one of hazard waste that content some chemical materials, such as Plumbum (Pb). A treatment method is needed to prevent the negative effect of Pb to environment. This research used constructed wetland with water hyacinth in batch flow reactor. Variation of wastewater concentration are $0 \%, 25 \%, 50 \%, 75 \%$ and $100 \%$ with sampling time until 12 days. Reactor with out water hyacinth is needed to know the performance of it. It is known that the highest removal of $\mathrm{Pb}$ is after 12 days running, where the level of removal efficiency is depend on the variation of wastewater concentration. The efficiency of removal on $25 \%$ and $50 \%$ with $0,0318 \mathrm{mg} / \mathrm{l}$ and $0,0675 \mathrm{mg} / \mathrm{l}$ of $\mathrm{Pb}$ as input is less than 0,001 $\mathrm{mg} / \mathrm{l}$. Reactors with $75 \%$ and $100 \%$ of wastewater have $88,86 \%$ and $17,31 \%$ of removal efficiency. Water hyacinth contributed in removing of $\mathrm{Pb}$ in wastewater.
\end{abstract}

Keywords : Constructed wetland, laboratory wastewater, plumbum, water hyacinth. 


\section{Pendahuluan}

Laboratorium merupakan sara penunjang bagi kegiatan riset di duni perguruan tinggi. Berbagai aktivitas pengujian dengan menggunakan bahan-bahan kimia berbahaya menjadikan limbah laboratorium sebagai salah satu limbah yang cukup berbahaya (hazard waste) yang harus diolah terlebih dahulu sebelum dibuang ke badan air penerima. Salah satu kandungan bahan berbahaya yang sering terdapat dalam limbah laboratorium adalah logam berat Timbal $(\mathrm{Pb})$ dengan kadar di atas baku mutu yang diijinkan. Ironisnya banyak sekali laboratorium yang tidak mempunyai sistem pengolahan limbah yang mewadai dan langsung membuang limbahnya ke badan air penerima. Hal ini tentu saja sangat berbahaya dan menjadi salah satu penyebab terjadinya pencemaran lingkungan. Faktor biaya sering menjadi penyebab utama tidak adanya sistem pengolahan limbah laboratorium ini. Dengan kondisi tersebut, maka perlu dipikirkan suatu cara atau terobosan untuk mengatasi permasalahan ini, yaitu teknologi pengolahan limbah yang mudah, murah dan mempunyai efisiensi tinggi.

Constructed Wetland (CW) dengan menggunakan tumbuhan Eceng gondok merupakan salah satu alternatif pengolahan air limbah sebelum dibuang kebadan air penerima. Pengolahan limbah dengan Constructed Wetland memanfaatkan mikroorganisme dalam tanah dan tanaman dalam areal tersebut. Dalam sistem ini terjadi akivitas pengolahan seperti sedimentasi, filtrasi, gas transfer, adsorbsi, pengolahan kimia dan pegolahan biologis karena akivitas mikrorganisme dalam tanah dan aktivitas tanaman untuk proses fotosintesis, pengoksida dan plan uptake (Metcalf \& Eddy, 1993). Dalam beberapa hal sistem ini menguntungkan karena biayanya murah, sederhana, dan memiliki kemampuan proses meminimalisasi limbah yang tinggi.

Tujuan dari penelitian ini adalah untuk mengakaji tingkat efektivitas $\mathrm{CW}$ dengan memanfaatkan tumbuhan Eceng gondok dalam menurunkan kandungan $\mathrm{Pb}$ dalam limbah laboratorium serta mengkaji pengaruh konsentrasi limbah terhadap tumbuhan Eceng gondok.

\section{Metode Penelitian}

\section{Limbah Laboratorium}

Limbah yang dipergunakan dalam penelitian ini adalah limbah cair dari Laboratorium Kualitas Lingkungan, Jurusan Teknik Lingkungan FTSP UII Yogyakarta. Variasi konsentrasi limbah yang dipergunakan adalah $0 \%, 25 \%, 50 \%, 75 \%$ dan $100 \%$. Variasi 0 
$\%$ berarti tidak ada larutan yang diuji murni air tanpa kandungan limbah laboratorium, konsentrasi $25 \%$ berarti dalam total volume limbah $25 \%$ nya adalah limbah laboratorium sedangkan $75 \%$ nya adalah pengencer yaitu air kran dari PDAM. Secara lebih detail mengenai variasi limbah dapat dilihat pada Tabel 1 berikut ini.

Tabel 1. Variasi Konsentrasi Limbah

\begin{tabular}{|c|c|c|c|c|}
\hline No & $\begin{array}{c}\text { Konsentrasi } \\
\text { Limbah Tanpa } \\
\text { Tanaman (\%) }\end{array}$ & $\begin{array}{c}\text { Konsentrasi } \\
\text { Limbah Dengan } \\
\text { Tanaman (\%) }\end{array}$ & $\begin{array}{c}\text { Volume } \\
\text { Limbah } \\
\text { (Liter) }\end{array}$ & $\begin{array}{c}\text { Volume } \\
\text { Pengencer } \\
\text { (Liter) }\end{array}$ \\
\hline 1 & 100 & 100 & 100 & 0 \\
\hline 2 & 75 & 75 & 75 & 25 \\
\hline 3 & 50 & 50 & 50 & 50 \\
\hline 4 & 25 & 25 & 25 & 75 \\
\hline 5 & 0 & 0 & 0 & 100 \\
\hline
\end{tabular}

\section{Tumbuhan Eceng gondok}

Tumbuhan Eceng gondok yang dipergunakan berasal dari kolam atau sawah di daerah Maguwo Sleman. Sebelum tumbuhan ini dipergunakan untuk pengujian perlu dicuci terlebih dahulu dan kemudian ditanam dalam kolam yang berisi air sumur. Keseragaman tumbuhan uji dipertimbangkan dari kesamaan lokasi pengambilannya, umurnya yaitu dipilih yang berumur muda yang dapat dilihat dari morfologinya, ukuran tumbuhan dipilih yang seragam tingginya dan jumlah daunnya. Jumlah tumbuhan Eceng gondok dalam setiap reaktor $\mathrm{CW}$ diperhitungkan berdasarkan jarak tanam atau kepadatannya di dalam reaktor tersebut, dimana setiap rekator uji diberi tumbuhan ini dengan jumlah yang sama 20 buah.

\section{Reaktor CW}

Reaktor CW yang dipergunakan dibuat dari bahan kayu berukuran P x L x T yaitu 1 x 0,5 x 0,5 meter. Pada permukaan dalam reaktor dilapisi plastik sehingga tidak bocor. Semua reaktor diletakkan dalam sebuah rumah kaca untuk menjaga dari air hujan dan pengaruh lingkungan luar. Pada setiap reaktor diberi media tanah dengan tebal $10 \mathrm{~cm}$ yang dimaksudkan untuk melekatnya akar tumbuhan Eceng gondok pada dasar reaktor. Sistem pengaliran air limbah yang dilakukan yaitu secara batch.

\section{Waktu pengujian}

Waktu pengujian sampel dilakukan pada hari ke-0, 3, 6, 9 dan 12 dengan pertimbangan waktu tersebut merupakan waktu kontak system pengolahan secara alamiah (natural 
treatment) yang biasa dipergunakan. Variasi waktu pengambilan sampel juga dimaksudkan untuk mencari waktu kontak yang paling optimal dalam system CW yang diteliti tersebut.

\section{Analisis data}

Pada penelitian ini dipergunakan alat Atomic Absorption Spectrophotometer (AAS) untuk mengukur konsentrasi $\mathrm{Pb}$ dalam inlet maupun outlet setiap sampel yang diambil.

Untuk mengetahui tingkat efisiensi penurunan parameter uji yaitu $\mathrm{Pb}$ dipergunakan persamaan sebagai berikut :

$$
\eta=\left(\mathrm{C}_{0}-\mathrm{C}_{1}\right) / \mathrm{C}_{0} \times 100 \%
$$

dengan:

$$
\begin{aligned}
& \eta=\text { Tingkat esisiensi (\%) } \\
& \mathrm{C}_{0}=\text { konsentrasi } \mathrm{Pb} \text { di inlet } \\
& \mathrm{C}_{1}=\text { konsentrasi } \mathrm{Pb} \text { di outlet }
\end{aligned}
$$

Pengolahan data dengan menggunakan statistic yaitu Anova juga dilakukan untuk mengetahui tingkat signifikansi terhadap berbagai variasi yang direncanakan.

\section{Hasil dan Pembahasan}

\section{Tingkat penurunan $\mathrm{Pb}$}

Hasil penurunan $\mathrm{Pb}$ dalam reaktor $\mathrm{CW}$ dengan tumbuhan Eceng gondok adalah seperti yang terlihat pada Tabel 2 berikut ini.

Tabel 2. Konsentrasi $\mathrm{Pb}$ Pada Reaktor dengan Tumbuhan Eceng gondok

\begin{tabular}{|c|c|c|c|c|c|}
\hline Konsentrasi & $\begin{array}{c}\text { hari ke-0 } \\
(\mathrm{mg} / \mathrm{L})\end{array}$ & $\begin{array}{c}\text { hari ke-3 } \\
(\mathrm{mg} / \mathrm{L})\end{array}$ & $\begin{array}{c}\text { hari ke-6 } \\
(\mathrm{mg} / \mathrm{L})\end{array}$ & $\begin{array}{c}\text { hari ke-9 } \\
(\mathrm{mg} / \mathrm{L})\end{array}$ & $\begin{array}{c}\text { hari ke-12 } \\
(\mathrm{mg} / \mathrm{L})\end{array}$ \\
\hline $0 \%$ & 0,0038 & 0,0031 & $\mathrm{ttd}$ & $\mathrm{ttd}$ & ttd \\
\hline $25 \%$ & 0,0318 & 0,0185 & 0,0025 & $\mathrm{ttd}$ & ttd \\
\hline $50 \%$ & 0,0675 & 0,0563 & 0,0385 & 0,0105 & ttd \\
\hline $75 \%$ & 0,0769 & 0,0691 & 0,0539 & 0,0474 & 0,0086 \\
\hline $100 \%$ & 0,2397 & 0,2325 & 0,2192 & 0,2017 & 0,1982 \\
\hline
\end{tabular}

Ket : $\mathrm{ttd}=$ tidak terdeteksi $(<0.001)$

Dari tabel di atas dapat diketahui tingkat penurunan $\mathrm{Pb}$ setiap reaktor sebagaimana terlihat pada Tabel 3 berikut ini. 
Tabel 3. Tingkat Penurunan $\mathrm{Pb}$ pada setiap Reaktor Uji

\begin{tabular}{|c|c|c|c|c|c|}
\hline Konsentrasi & $\begin{array}{c}\text { hari ke-0 } \\
(\%)\end{array}$ & $\begin{array}{c}\text { hari ke-3 } \\
(\%)\end{array}$ & $\begin{array}{c}\text { hari ke-6 } \\
(\%)\end{array}$ & $\begin{array}{c}\text { hari ke-9 } \\
(\%)\end{array}$ & $\begin{array}{c}\text { hari ke-12 } \\
(\%)\end{array}$ \\
\hline $0 \%$ & 0 & 17,54 & 100 & 100 & 100 \\
\hline $25 \%$ & 0 & 41,93 & 92,24 & 100 & 100 \\
\hline $50 \%$ & 0 & 16,54 & 42,96 & 84,44 & 100 \\
\hline $75 \%$ & 0 & 10,19 & 29,91 & 38,36 & 88,86 \\
\hline $100 \%$ & 0 & 3,00 & 8,55 & 15,85 & 17,31 \\
\hline
\end{tabular}

Pengujian dengan menggunakan reaktor tanpa tumbuhan Eceng gondok adalah seperti yang terlihat pada Tabel 4 berikut ini.

Tabel 4. Konsentrasi Pb Pada Reaktor tanpa Tumbuhan Eceng gondok

\begin{tabular}{|c|c|c|c|c|c|}
\hline Konsentrasi & $\begin{array}{c}\text { hari ke-0 } \\
(\mathrm{mg} / \mathrm{L})\end{array}$ & $\begin{array}{c}\text { hari ke-3 } \\
(\mathrm{mg} / \mathrm{L})\end{array}$ & $\begin{array}{c}\text { hari ke-6 } \\
(\mathrm{mg} / \mathrm{L})\end{array}$ & $\begin{array}{c}\text { hari ke-9 } \\
(\mathrm{mg} / \mathrm{L})\end{array}$ & $\begin{array}{c}\text { hari ke-12 } \\
(\mathrm{mg} / \mathrm{L})\end{array}$ \\
\hline $0 \%$ & 0,0038 & 0,0034 & 0,0012 & ttd & Ttd \\
\hline $25 \%$ & 0,0318 & 0,0226 & 0,0107 & 0,0014 & ttd \\
\hline $50 \%$ & 0,0675 & 0,0583 & 0,0459 & 0,0213 & 0,0095 \\
\hline $75 \%$ & 0,0769 & 0,0706 & 0,0623 & 0,0468 & 0,0137 \\
\hline $100 \%$ & 0,2397 & 0,2362 & 0,2281 & 0,2217 & 0,2086 \\
\hline
\end{tabular}

Ket $:$ ttd $=$ tidak terdeteksi $(<0.001)$

Tingkat prosentase penurunan $\mathrm{Pb}$ tanpa tumbuhan Eceng gondok adalah seperti yang terlihat pada Tabel 5 berikut ini.

Tabel 5. Tingkat Penurunan $\mathrm{Pb}$ pada Reaktor tanpa Tumbuhan Eceng gondok

\begin{tabular}{|c|c|c|c|c|c|}
\hline Konsentrasi & $\begin{array}{c}\text { hari ke-0 } \\
(\%)\end{array}$ & $\begin{array}{c}\text { hari ke-3 } \\
(\%)\end{array}$ & $\begin{array}{c}\text { hari ke-6 } \\
(\%)\end{array}$ & $\begin{array}{c}\text { hari ke-9 } \\
(\%)\end{array}$ & $\begin{array}{c}\text { hari ke-12 } \\
(\%)\end{array}$ \\
\hline $0 \%$ & 0 & 10,53 & 68,42 & 100 & 100 \\
\hline $25 \%$ & 0 & 28,93 & 66,35 & 95,60 & 100 \\
\hline $50 \%$ & 0 & 13,63 & 32,00 & 68,44 & 85,93 \\
\hline $75 \%$ & 0 & 8,19 & 18,99 & 39,14 & 82,18 \\
\hline $100 \%$ & 0 & 1,46 & 4,84 & 7,51 & 12,97 \\
\hline
\end{tabular}

Penurunan konsentrasi $\mathrm{Pb}$ yang nyata terjadi mulai hari ke-3 sampai hari ke-12, ini terlihat pada reaktor $0 \%$ pada hari ke-3 terjadi penurunan sebesar $17,54 \%$ dengan konsentrasi awal 0,0038 mg/L menjadi 0,0031 mg/L. Dihari ke-6 dan selanjutnya konsentrasi Pb pada reaktor $0 \%$ sudah tidak dapat terditeksi karena batas minimum pembacaan alat (AAS) hanya sampai $0,001 \mathrm{mg} / \mathrm{L}$. Pada reaktor $25 \%$ terjadi penurunan sebesar 92,24\% sampai hari ke-6 dari konsentrasi awal 0,0318 mg/L menjadi 0,0025 mg/L, di hari ke-9 sampai ke12 konsentrasi $\mathrm{Pb}$ sudah tidak dapat terbaca lagi. Konsentrasi pada reaktor $50 \%$ effisiensi 
penurunannya sebesar 84,44 \% sampai hari ke-9 dari konsentrasi 0,0675 mg/L menjadi 0,0105 mg/L, pada hari ke-12 konsentrasi sudah tidak dapat terditeksi lagi. Selanjutnya effisiensi pada reaktor $75 \%$ sebesar 88,86 \% sampai hari ke-12 dari konsentrasi awal $0,0769 \mathrm{mg} / \mathrm{L}$ menjadi $0,0086 \mathrm{mg} / \mathrm{L}$ Pada reaktor $100 \%$ effisiensi yang terjadi sangat kecil hanya $17,31 \%$ dari konsentrasi awal 0,2397 mg/L menjadi 0,1982 mg/L.

Dilihat dari hasil analisa di atas, nilai effisiensi yang paling kecil terdapat pada konsentrasi reaktor $100 \%$. Hal ini dapat disebabkan karena konsentrasi limbah yang terlalu pekat sehingga sukar untuk terurai dan diserap oleh tumbuhan Eceng gondok. Kemampuan tumbuhan Eceng gondok dalam menyerap kadar $\mathrm{Pb}$ dengan konsentrasi tinggi menjadi kurang optimal karena $\mathrm{Pb}$ tersebut mengganggu pertumbuhannya dan bahkan dapat menyebabkan kematian tumbuhan tersebut. Pada penelitian dengan menggunakan tumbuhan Eceng gondok untuk menurunkan kadar Sianida $(\mathrm{CN})$ dalam air limbah terlihat bahwa pada konsentrasi rendah tumbuhan dapat hidup normal, sedangkan pada konsentrasi tinggi tumbuhan tersebut mengalami gangguan diantaranya daunya mengering (Ebel $\mathrm{M}$, 2006). Proses pengolahan air limbah dengan menggunakan sistem constructed wetland ini menunjukan proses penurunan kandungan air limbah yang bervariasi sesuai dengan tingkat konsentrasi dari air limbah dalam reaktor. Secara umum dapat dilihat bahwa semakin tinggi tingkat konsentrasi air limbah yang digunakan maka akan semakin rendah kemampuan removal yang dihasilkan.

Penurunan kadar $\mathrm{Pb}$ oleh tumbuhan Eceng gondok dimulai dengan aktivitas mikroorganisme dan tanaman dalam Constructed wetland. Proses pengolahan dalam Constructed wetland sangat bergantung pada aktivitas mikroorganisme dalam tanah dan tanaman. Berdasarkan hasil penelitian diketahui bahwa aktivitas mikroorganisme ini sangat bergantung pada aktivitas akar tanaman dalam sistem Constructed wetland untuk mengelurkan oksigen (Gopal, 1999 dalam Siswoyo, 2002).

Penurunan kadar $\mathrm{Pb}$ yang terjadi karena proses penyerapan dan transpirasi dipengaruhi oleh luas permukaan daun dan jumlah akar yang dimiliki oleh tumbuhan Eceng gondok. Proses transpirasi terjadi karena adanya penguapan air dari permukaan sel mesofil yang basah dan uapnya akan keluar melalui stomata yang terdapat pada permukaan daun. Proses transpirasi yang tinggi akan diikuti dengan proses penyerapan yang tinggi pula oleh akarakar tumbuhan Eceng gondok. 
Menurut Connel dan Miller (1984) logam yang terdapat di lingkungan akan diserap ke dalam tanaman melalui stomata dan sistem perakaran. Unsur $\mathrm{Pb}$ masuk melalui stomata, dimana $\mathrm{Pb}$ yang dihasilkan dari proses alam maupun proses industri akan bergabung dengan partikel-partikel udara dan masuk kedalam tanaman pada saat stomata daun tanaman membuka, sedangkan unsur $\mathrm{Pb}$ terabsorbsi oleh akar pada saat akan meng absorbsi air dan unsur hara.

Proses absorbsi berawal dari penyerapan $\mathrm{Pb}$ oleh akar kemudian diendapkan di permukaan akar, $\mathrm{Pb}$ secara perlahan akan mengumpul dalam sel yaitu dalam diktiosoma (badan golgi). Dari gelembung diktiosoma akan bermigrasi ke dinding sel dan akhirnya $\mathrm{Pb}$ terakumulasi plasindema dinding sel daun. Lebih dari $90 \% \mathrm{~Pb}$ tersimpan dalam dinding sel daun dan pucuk, hanya sejumlah kecil $\mathrm{Pb}$ yang dapat menembus buah dan biji.

Dari fenomena yang terjadi pada proses penyerapan logam $\mathrm{Pb}$, dapat terlihat bahwa kandungan logam yang telah diserap oleh akar menuju ke batang dan terakumulasi di bagian daun, walaupun semua kandungan logam tersebut tidak terbawa sampai ke daun. Hal ini terjadi dikarenakan adanya proses Rhizofiltrasi. Rhizofiltrasi adalah pemanfaatan kemampuan akar tanaman untuk menyerap, mengendap dan mengakumulasi logam-logam pada aliran limbah. Rhizofiltrasi ini merupakan salah satu metode dalam fitoremediasi. Fitoremediasi itu sendiri adalah penggunaan tumbuhan untuk menghilangkan, memindahkan, menstabilkan atau menghancurkan bahan pencemar, baik senyawa organik maupun senyawa anorganik. Pada prinsipnya tumbuhan tidak membeda-bedakan antara unsur esensial dan non esensial. Setiap unsur yang ada dalam media tempat hidupnya dapat diharapkan diserap oleh akar dengan laju yang sesuai dengan konsentrasinya dalam tanah. Jika dibandingkan antara CW dengan tumbuhan Eceng gondok dan tanpa tumbuhan Eceng gondok terdapat perbedaan tingkat penurunan $\mathrm{Pb}$ yang terjadi dari hari ke hari. Hal ini menunjukkan bahwa tumbuhan Eceng gondok memegang peranan yang cukup besar dalam sistem tersebut. Pada konsentrasi air limbah rendah, kedua sistem baik yang dengan tumbuhan Eceng gondok maupun yang tanpa menggunakan kemampuan reaktor hampir sama. Seperti yang telah dijelaskan sebelumnya bahwa dalam $\mathrm{CW}$ selain tumbuhan, tanah yang ada pada dasar reaktor yang di dalamnya terdapat mikroorganisme juga memegang peranan yang cukup besar. Selain itu proses sedimentasi juga berperan dalam penurunan berbagai kontaminan baik logam berat maupun berbagai organik (Jill G. Bell, 1998). Peran tumbuhan cukup penting karena mampu mengontrol atau menghambat laju aliran air melalui batang maupun akarnya sehingga akan ada waktu utnuk terjadinya sedimentasi. 
Kemampuan tumbuhan Eceng gondok dalam menurunkan kontaminan berubah menurut waktu dan konsentrasi dari bahan pencemar tersebut (Amr Adel El-Agroudy, 1999).

\section{Kondisi Tumbuhan Eceng gondok}

Pengamatan pengaruh limbah terhadap tumbuhan Eceng gondok dilakukan secara visual dengan melihat kondisi fisik, misalnya perubahan warna daun, kondisi akar dan jumlah daun yang kering serta membusuk. Dari hasil pengamatan visual tersebut diketahui bahwa tumbuhan Eceng gondok pada reaktor dengan konsentrasi limbah $0 \%$ dapat hidup dengan normal dan berkembang dengan baik. Pada reaktor dengan konsentrasi air limbah $25 \%$ tumbuhan Eceng gondok dapat hidup dengan normal seperti halnya pada reaktor pertama. Sedangkan pada reaktor dengan konsentrasi air limbah 50 \% sampai dengan konsentrasi air limbah $100 \%$, tumbuhan Eceng gondok mengalami gangguan, yaitu daunnya menguning dan akarnya membusuk. Bahkan pada reaktor dengan konsentrasi air limbah $100 \%$, daun, batang dan akar tumbuhan Eceng gondok menjadi tidak normal yaitu membusuk dan kemudian kering. Meskipun konsentrasi $\mathrm{Pb}$ dalam limbah laboratorium yang dipergunakan dalam penelitian ini tidak terlalu tinggi tetapi tumbuhan Eceng gondok tetap terganggu. Hal ini dikarenakan di dalam limbah tersebut juga terdapat berbagai kontaminan lain yang berupa logam berat $\mathrm{Cr}$, Hg serta kadar COD yang cukup tinggi. Selain faktor konsentrasi limbah, pertumbuhan Eceng gondok juga berubah seiring dengan perubahan waktu dimana pada akhir pengujian yaitu pada hari ke-12 beberapa Eceng gondok layu dan mati.

\section{Kesimpulan dan Saran}

Dari data-data dan uraian di atas maka dapat ditarik kesimpulan sebagai berikut :

1. $\mathrm{CW}$ dengan menggunakan tumbuhan Eceng gondok mampu menurunkan kadar $\mathrm{Pb}$ dalam air limbah laboratorium dengan tingak efisiensi berbeda tergantung konsentrasi limbah yang dipergunakan.

2. Pada konsentrasi limbah $25 \%$ dan $50 \%$ dengan input $0,0318 \mathrm{mg} / 1 \mathrm{dan} 0,0675 \mathrm{mg} / \mathrm{l}$ diperoleh output kurang dari $0,001 \mathrm{mg} / 1$ yang merupakan batas terendah pembacaan AAS yang dipergunakan. Pada konsentrasi air limbah $75 \%$ kemampuan penurunan mencapai 88,86 \% sedangkan pada konsentrasi limbah $100 \%$ tingkat penurunan yang terjadi hanya $17,31 \%$.

3. Peran tumbuhan Eceng gondok terlihat dari perbedaan tingkat efisiensi penurunan $\mathrm{Pb}$ yang terjadi antara reaktor dengan tumbuhan dibanding reaktor tanpa tumbuhan tersebut. 
4. Pada konsentrasi limbah yang cukup tinggi tumbuhan Eceng gondok mengalami gangguan dan bahkan mati.

\section{Daftar Pustaka}

1. Amr Adel El-Agroudy, 1999, Investigation of Constructed Wetlands Capability to Remove Mercury from Contaminated Waters, Department of Building, Civil and Environmental Engineering, Thesis for Doctoral Degree of Concordia University, Montreal, Quebec, Canada.

2. Connel,W., Des,Miller., and Gregory., 1984, Chemistry and Ecotoxicologi of pollutan, A Willey Interscience Publication, New York.

3. Ebel M, 2006, Cyanida Phytoremediation by Water Hyacinth (Eichornia crassipes), Elsevier, Chemosphere 66 (2007) pages 816-823.

4. Jill. G. Bell, 1998, Vegetation and water Quality Monitoring of a Constructed wetlands for the Treatment of Urban Stormwater Runoff, Master Thesis, Faculty of Environmental Design, University of Calgary.

5. Metcalf and Eddy, 1991, Wastewater Engineering Treatment, Disposal and Reuse,

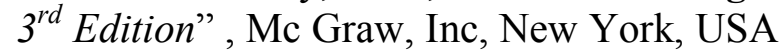

6. Siswoyo E, 2002, Pengolahan Air Limbah Domestik dengan Menggunakan Sistem Constructed Wetlands, Proseeding Seminar Nasional Jurusan Teknik Lingkungan UII Yogyakarta. 